\title{
Evaluation of Human Rights, Citizenship and Democracy Course by Teacher's Vision
}

\author{
Gülsün Şahan ${ }^{1, *} \&$ Ayşegül Tural ${ }^{1}$ \\ ${ }^{1}$ Faculty of Education, Bartin University, Bartin, Turkey \\ *Correspondence: Faculty of Education, Bartin University, Bartin, Turkey. E-mail: gulsunsahan@hotmail.com
}

Received: March 2, 2018 Accepted: March 16, 2018 Online Published: March 30, 2018

doi:10.5430/wje.v8n2p46 URL: https://doi.org/10.5430/wje.v8n2p46

\begin{abstract}
Human Rights, Citizenship and Democracy Course draws attention to with topics such as human rights, effective citizenship. In terms of content, it has an important place in contemporary education concept. It is thought that the Human Rights, Citizenship and Democracy course will benefit the social structure because of its content and the outputs that can be obtained at the end of the teaching process. The purpose of this research is to examination the opinions of teachers on the fourth class Human Rights, Citizenship and Democracy course. For this purpose, phenomenology from qualitative research methods were used in the study. As a result of the research, it was found that teachers had positive opinions about Human Rights, Citizenship and Democracy lesson. The results obtained include statements that administrators should have support for this course and the course should not be graded.
\end{abstract}

Keywords: human rights, citizenship, democracy, primary school

\section{Introduction}

Education is essential building block of a society. Importance of education that is the most important deterministic factor to shape society comes into more prominence every day. While importance of education is understood, individuals can improve themselves and present ideas on development of social order. Especially in these days and time; existing citizenship perception in communal life also changes and improves by effect of cultural and technological advances depend on this improvement. Today importance of democratic society and cultural substructure is emphasized. At this point, it is expected that individuals who form the society should adopt, internalize democratic behaviors and reflect on their lives. Essentially, democratic behavior is one of the abilities that would be gained since childhood period. For this reason, it can be said that learning a new behavior and making learnt behavior an ability would be harder for adults ongoing years. It is known that the most important institutions are schools for individual and communal development. Every child in education age must continue to school. Democracy, citizenship, human rights education is important concept that its foundation is laid under school roof. Addition to important functions of schools in education process; its contribution to citizenship, democracy and human rights education is seen as quite valuable for individuals. According to Howe and Cowell (2005); individuals gain experience, improve themselves and take place in communal life more active and more participative both in school and out of school by maintained democracy and citizenship education. Citizenship, democracy and human rights concepts are advancement focused and dynamic structures that cannot be think separately from each other. People and societies are always in positon of development. Change of expectation and concept of right, freedom, democracy and active citizenship is also unescapable in this development and improvement process (Özbek, 2017) because while people changes; democratic attitudes and citizen type that community wants can also differentiate in time. However, making concepts like right, freedom and democracy a behavior is a hard process and wants endeavor by this differentiation. It is important to support these cognitive, affective and ability-based structures in this hard process (Bağl1, 2013). This is the only possible way to show effects of human rights and citizenship concepts on attitude and behaviors. It is also thought that firstly responsible people are teachers. People who live in territory of a country is accepted as citizen of this country and they can benefit from all social, economic, political rights that this country gives to its citizens (Starkey, 2002). Citizenship, human rights and democracy education is a global education and addresses all humanity. People explore to belong to society that they live in as an individual and exist as active citizens who respect to others by this education process (Andreopouolos, 2002). Of course, citizenship, human rights and democracy education is seen as important 
because it also contains to be active citizen, understand all sides of human rights and fix misknown applications of related lesson addition to these information (Akbaşl1, 2009). Importance of human rights, civic and democracy education in education process is also understood in our country like all world and for that reason it is satisfied to take place in education program as a course. Compulsory education age in turkey covers the 6-13 age group children in accordance with article 22 of law no1739. It is understood that it also covers all general, technical and vocational education institutions and centers that give formal or non-formal education that secondary school is built upon primary school in accordance with article 26 of relevant law. Democracy education that aims to develop a democratic attitude by start of education life take a place as one of the fundamental principles of National Education (www.meb.gov.tr). When look at the general history of citizenship education in Turkey, it is seen that it takes place by names of Civics Information, Citizenship Information, Citizenship Education since 1924 in schools and start to be applied in 8. grade by names of Citizenship and Human Rights Education during 1995-1996 education years. In 1997-1998 education years, it started to be practiced in 7. and 8. grades. In 2005, it is taken off program. 2010-2011 education years; it is again put to program as one-hour elective course once week in 8. grade (Coşkun Keskin \& Keskin, 2009; Sağlam \& Hayal, 2015, cit. Gürel, 2016). In 126 numbered decisions under date of 09/14/2010; it become a must course in 8 . grade in primary school by name of Democracy Education. According to 06/25/2017 dated and 69 numbered decision of MEB Turkish Education Board; "Human Rights, Civic and Democracy" course would be given as 2 hours must course in 4. grade in primary school being valid from 2015-2016 education years. In this course; mostly it is aimed students to gain fundamental values related to Human Rights, Civic and Democracy and make these values their lifestyles and cultures rather than transmitting technical information. Main purpose is students to gain information, ability, value and attitude regarding internalizing humanitarian values, behaving people fair and equally, making decisions based on collaboration and democracy, obeying rules, taking responsibility for improvement of living together by this course (MEB, 2015). This course consists of being human, right, freedom and responsibility, justice and equality, consensus, rules, living together units (MEB, 2017). It is believed that this study that aims to put forward opinions of teachers regarding primary school 4. grade Human Rights, Civic and Democracy Course can make attribution to related field literature and it is important because it reveals students' ability achievement towards right, freedom, democratic attitude and citizenship perception by teachers' view.

\subsection{Introduce the Problem}

Aim of this research is to take opinions of teachers regarding Human Rights, Civic and Democracy Course that is put to effect in primary school 4 grade in 2015-2016 education years, determine problems that occurs during teaching course and implementation and improve solution suggestions regarding encountered problems. Questions regarding importance, duration, program of Human Rights, Civic and Democracy Course; expected development from students, encountered difficulties implementation, expected changes to be done, used method, technique and strategies, used material, education that teachers had taken in this topic, approach of school management and recommendations have been addressed to teachers to reach this aim.

\section{Method}

In this research, phenomenology pattern that is one of the qualitative research methods has been used fitting the purpose of study. In phenomenology pattern, it is studied on facts that we know but we are aware in-depth or in details. Using phenomenology pattern could be suitable in studies that try to explain events which are not unfamiliar to us, but we cannot perceive it fully (Yıldırım \& Şimşek, 2008). Opinions of teachers who give Democracy, Citizenship and Human Rights course in 4. grade have been taken via half-structured interview from by researchers in this study. Interview form has been formed after field literature survey and edited in accordance with two academic members who are social science education, assessment and evaluation specialist. Then; interview form's last form is constituted by making pre-implementing to 3 educators who are teachers in 4. grade.

\subsection{Study Group}

Study group of research are 4. grade teachers who work in several government and private school in Bartın-Turkey. Study group consists of eight class teachers who are selected by easy accessible sample method. Teachers' opinions have been obtained face to face. Opinions have been taken regarding interview form by voice record and in written from ones who don't want record and all opinions have been transferred to computer environment. Content and qualitative analyze have been done according to themes that are formed by researchers; obtained findings have been interpreted. Direct quotations have been given for reliability of research. Teachers who take place in study group are coded as female and male; men is expressed as MT1, MT2 ..; women is FT1, FT2... In the research; opinions of 8 teachers have been taken as 5 males, 3 female teachers. Teachers who attend to research are 1 person in '20-24 age 
range, 1 person ' $30-34$ age range', 1 person in '35-39 age range', 3 people in ' $40-44$ age range' and 2 people in ' $44-49$ age range'. One of the participants has 1 year, one of them has 8 years, one has 13 years and 5 of them have 20 years' education experience. All of the participants work as class teachers; 6 of them have graduated from teaching department and 2 of them have graduated from different departments.

\section{Results}

Obtained findings from analyze of opinions regarding research's questions are given in this part.

3.1 Findings on Importance of Human Rights, Civic and Democracy Course

Teacher opinions on importance of Human Rights, Civic and Democracy Course can be seen in Table 1.

Table 1. Importance of Course

\begin{tabular}{lll}
\hline Importance & People & $\mathrm{n}$ \\
\hline Important and necessary & FT1-FT2-FT3-MT4-MT5-MT6-MT7-MT8 & 8 \\
\hline
\end{tabular}

When Table 1. is examined; it is seen that all of the teachers have similar opinions about that this course is important and necessary. One of the teachers makes a statement like;

"I think this course can make same contributions gain to children by appending to other courses in interdisciplinary way" (MT4) another teacher expresses his opinions like;

"Definitely is necessary but materials of course should be enhanced and its implementation fields should be formed in schools" (MT6). It is seen that all teachers have consensus about hat this course is important and necessary.

\subsection{Findings regarding duration of Human Rights, Civic and Democracy Course}

Findings on whether duration of Human Rights, Civic and Democracy Course is enough or not enough are in Table 2.

Table 2. Course Duration

\begin{tabular}{lll}
\hline Course duration & People & $\mathrm{f}$ \\
\hline Enough & FT1-FT2-MT4-MT5-MT7-MT8 & 6 \\
Not Enough & FT3-MT6 & 2 \\
\hline
\end{tabular}

When Table 2 is examined; it is seen that 6 teachers think allocated time to this course is enough, 2 teachers finds as inadequate. A teacher says that regarding inadequacy of time;

"Two hours in a week aren't enough in point of its importance and practicality in our daily life" (MT6). It is seen that most of the teachers think as course duration is 'enough'.

\subsection{Findings Regarding Program of Human Rights, Civic and Democracy Course}

Findings on whether Human Rights, Civic and Democracy Course program is analyzed by teachers or not are in Table 3.

Table 3. Analyze of Program

\begin{tabular}{lll}
\hline Program & People & f \\
\hline Examined & FT3-MT6-MT7-MT8 & 4 \\
Not examined & FT1-FT2-MT4-MT5 & 4 \\
\hline
\end{tabular}

When Table 3 is evaluated; it is seen that 4 teachers examined program, 4 of them didn't. One of the teachers who evaluate the program says that;

"Program is suitable to class level and as its content in point of course's importance, but questions are too much in classes that have over participation with regards to lack of time" (MT6); teacher who dint evaluate program express that program didn't reach and teacher guide book arrive late. In this point, a teacher says;

"We couldn't examine because education program didn't reach to us. We have course book and annual plan that is downloaded from internet" (FT2). It is seen that half of teachers analyzed program of Human Rights, Civic and 
Democracy Course which is put to practice in primary school 4. grade since 2015, half of them didn't. It can be said that teacher who analyzed program would make more contribution to this course to reach its aims.

3.4 Findings on Improvements That Teachers Expect from Student Result of Human Rights, Civic and Democracy Course Findings regarding teachers' expectations from student in Human Rights, Civic and Democracy Course are in Table 4.

Table 4. Teacher Expectation from Student Who Take Course

\begin{tabular}{lll}
\hline Expectations & People & $\mathrm{f}$ \\
\hline Know his/her rights, assert, & FT3-MT4-MT5-MT6 & 4 \\
Fair and equalitarian, & FT1-FT2-MT4-MT8 & 4 \\
Tolerant, & FT2-MT8 & 2 \\
Respectful to rights, individuals and institutions, & FT2-FT3 & 2 \\
Able to empathize & FT2- MT8 & 2 \\
Express him/herself, & MT5 & 1 \\
Interpret & MT5 & 1 \\
Know his/her responsibilities, & MT6 & 1 \\
Independent, social, free, thing, criticize, & MT7 & 1 \\
Well- behaved individual & MT8 & 1 \\
Thoughtful, helpful, & FT2 & 1 \\
\hline
\end{tabular}

When Table 4 is examined, it is understood that 4 teachers expect students to be people who know his/her rights and assert, fair and equalitarian, 2 teachers expect to be tolerant, 2 teachers expect to be respectful to rights, individuals and institutions, 2 teachers expect to be able to empathize. Furthermore, teachers expect students to express themselves, make interpretations, know their responsibilities, be independent and social, think free, criticize, be well-behaved, helpful and understanding. In this point a teacher expresses his opinions like;

"I expect to change and improve as individuals who are well-behaved and internalize some concepts like justice, equality, tolerance, empathy because of that human is intrinsically a social existence" (MT8). Another teacher attracts notice on positive sides of this course by saying that;

"They noticed their rights, expressed themselves, learnt to comment and gave identical answers to open ended questions" (MT5). When findings are evaluated generally, it is seen that teachers think students would notice human rights and democracy, gain good citizen virtue.

3.5 Findings on Encountered Difficulties Regarding Implementation of Human Rights, Civic and Democracy Course

Ideas on difficulties that teachers encounter in implementation of Human Rights, Civic and Democracy Course are seen in Table 5.

Table 5. Encountered Difficulties in Implementation of This Course

\begin{tabular}{lll}
\hline Difficulties & \multicolumn{1}{c}{ People } & $\mathrm{n}$ \\
\hline Texts are long, unknown words are too & FT1, FT2, MT5, MT7, MT8 & 5 \\
Program is heavy for level & MT7, MT8 & 2 \\
There are problems in implementation & FT3 & 1 \\
\hline
\end{tabular}

When Table.5 that ideas regarding encountered problems in implementation of this course exist in is examined, it is seen that firstly 5 teachers finds texts as long and think there are too many unknown word. While 2 teachers state program is heavy for student level, a teacher expresses there are problems in implementation not in theory. According to findings, one of the teachers who remarks texts are long and unknown word are many says that;

“Texts are long and unknown word are many, students' understanding and interpreting is hard, adding students who have difficulty to state themselves and in oral expression to lesson is hard, some of the texts doesn't have continuation and end" (MT5). A teacher who thinks program is heavy for students' level express himself as;

"Firstly, program is too heavy, these terms don't make any sense to student. It is wrong to give that much intangible words to students who are period of intangible processes yet" (MT8). In implementation topic, another teacher also says; 
"There is problem in sense of student in implementation not in theory, program should be improved in education matter" (FT3) According to obtained findings; when problems that are encountered during implementation of this course are examined, it is understood that texts are long and unknown words are many. There are teachers who think program is heavy for 4 . grade students.

\subsection{Findings Regarding Expected Changes in Human Rights, Civic and Democracy Course}

What kind of changes that teachers want in Human Rights, Civic and Democracy Course and implementation level are in Table 6.

Table 6. Expected Changes to Be Done in This Course

\begin{tabular}{lll}
\hline Recommendations & People & $\mathrm{f}$ \\
\hline Texts should be simplified, & FT2, FT1, MT8 & 3 \\
Students shouldn't be evaluated by grade, & MT8, MT7 & 2 \\
Activities should be & FT2 & 1 \\
Atatürk matter should take place more, & FT3 & 1 \\
Video, visuals should exist, & FT2 & 1 \\
Books should be simplified, & FT2 & 1 \\
Visuals should be in course, & FT2 & FT3 \\
Value and rights should be more, & FT3 & 1 \\
Child abuse topic should enter to curriculum, & MT7 & 1 \\
Activities like drama should be & MT8 & 1 \\
Core of course should be given, not terms, & MT8 & 1 \\
Lesson should be taught by doing and living, & & 1 \\
\hline
\end{tabular}

When Table 6 is examined, three teachers think texts should be simplified, it is seen that two teachers think this course shouldn't be evaluated by grade. 2 teachers point out activities should take more place. A teacher explains his recommendations on course like;

"Firstly, program is heavy for 4. grade, it should start from 5. grade, even 6. grade. I think it would start from 4. grade, terms should be taken off and they shouldn't be evaluated by grade, course should be done by implementation and it should be from an environment and culture that there are similar events in" (MT8). Another teacher also lists like;

"Core of course should be given not terms; terms shouldn't be given in 4. grade, it should be told by doing and living, there shouldn't be an exam, they shouldn't be evaluated by exam" (MT8) It is remarked to teachers that they should prepare video and presentations related to course while performing class and reach to these sources over 'eba.gov.tr' is important. They said that book should be simplified, topic should be concretized by giving more place to visual materials in course book and giving more place to Atatürk matter would be appropriate in topic of teaching our rights and values. Additionally, it is mphasized that adding of child abuse to curriculum and raising children awareness is important. There are ideas of that activities as kinds of drama should be given in course; terms shouldn't be given in 4. grade, topics should be told to students by doing and living, evaluation by grade shouldn't be. When teacher recommendations are evaluated generally, it gets attractions to topics of that concrete activities should take place in this course rather than terms, exam stress shouldn't be lived, children should be informed about child abuse.

3.7 Findings Regarding Used Method, Technique and Strategies in Human Rights, Civic and Democracy Course

Teacher opinions on used method and techniques in Human Rights, Civic and Democracy Course is seen at Table 7.

Table 7. Used Method, Technique and Strategies

\begin{tabular}{lll}
\hline Method, technique and strategy & People & f \\
\hline Question, answer, expression & FT2, MT4, MT5, MT7, MT8 & 5 \\
Discussion & MT4, MT7 & 2 \\
Group work & MT7 & 1 \\
Brain storm & MT8 & 1 \\
Visual presentation & FT2 & 1 \\
New technologies & FT3 & 1 \\
\hline
\end{tabular}


Question of how do you teach is directed to teachers and obtained answer take place in Table 7. When Table 7 is examined, at first level it is seen 5 teachers use question answer expression technique while performing course. 2 teachers expressed that we use discussion also. Group work, brain storm and visual presentation exist also in other methods. In this topic, a teacher says;

"I give voice to every student and make them give examples from their close environment about learnt concept and its practices. I want them to give examples from family, neighbors, close friends, groups" (MT6). A teacher also voices that;

"We use new methods like harmonization by daily life, concertation, smart board, technology help, brain storm" (FT3). However, it is understood that mostly teachers perform course from course book.

\subsection{Findings on used sources in Human Rights, Civic and Democracy Course}

Findings regarding sources that teachers use in Human Rights, Civic and Democracy Course are in Table 8.

Table 8. Used Sources in Course

\begin{tabular}{lll}
\hline Sources & People & $\mathrm{f}$ \\
\hline Course book & FT1, FT2, FT3, MT4, MT5, MT6, MT7, MT8 & 8 \\
Internet & FT1, FT2, MT4, MT5 & 4 \\
Visuals & FT1, FT3 & 2 \\
Constitution & MT6 & 1 \\
\hline
\end{tabular}

When Table 8 is examined; which sources do you use while teaching question is directed to teachers, when obtained answers are analyzed; all teachers express that we use course book. 4 teachers state to use internet and download slide and question. 2 teachers express that we perform this course by slide, video and visual presentations. A teacher also explains to use constitution in course. Relation to used sources in course, while a teacher is saying that;

"I don't use any source except course book, I solve exam questions with student by downloading from the internet" (MT5). Another teacher indicates to benefit from constitution by saying that;

"Course book, sometimes constitution, student and close environment" (MT6). Related to used source in this course, a teacher clarifies her study by saying that;

"I make students watch slides from the internet in accordance with course" (FT1) When views of teachers are examined generally, it can be said that teachers use video and tests that are downloaded from the internet except course book.

\subsection{Findings on Taken Education on Human Rights, Civic and Democracy Course Implementation}

Findings on whether teachers took any education related with field toward Human Rights, Civic and Democracy Course implementation or not are in Table 9.

Table 9. Education that Teachers Took for This Course

\begin{tabular}{lll}
\hline Education & People & $\mathrm{f}$ \\
\hline No & FT1-FT2-FT3-MT4-MT5-MT6-MT7-MT8 & 8 \\
\hline
\end{tabular}

When Table 9 is examined, it is understood that all of teachers don't have any education on this course. All teachers indicate that we didn't attend any course or seminar related to this course. It is expressed that previously this course has been given in secondary school level and instructed by social science, philosophy teachers but class teachers didn't take any training in education faculties and a seminar should be given firstly towards course that is newly put. In toward of this finding, one of the causes of inadequacy of teacher in point of teaching course can be thought as they didn't take enough training and education regarding teaching this course.

3.10 Findings on Attitude of School Management regarding Human Rights, Civic and Democracy Course

Finding regarding behaviors of school managers in Human Rights, Civic and Democracy Course implementation are seen in Table 10. 
Table 10. Attitude of School Management to This Course

\begin{tabular}{lll}
\hline Managers & People & $\mathrm{f}$ \\
\hline Positive & FT2-MT7- MT8- FT3 & 4 \\
No difference & MT5-. MT6-FT1 & 1 \\
They should be model & MT4 & 1 \\
\hline
\end{tabular}

When Table 10 is examined, 4 teachers state school managers exhibit positive attitude regarding this course. Moreover, 3 teachers say school managers don't have any different approach to this course. On the other hand, a teacher expresses attitude of school manager is important and says;

"School managers can help by being role model" (MT4). Half of the teachers indicate attitude of school managers on this course is positive, some of the teachers says they don't have any different attitude about this course. It is emphasized that manager behaviors are important in point of being role model.

\section{Discussion}

Since this study is a qualitative study with a small group, the results are limited by the study group. The results of the research cannot be generalized to the field but give an idea about the subject. According to results that are obtained by interpreting findings of study; most of the teacher think allocated time to "Human Rights, Civic and Democracy" course is 'enough'. It is obtained result of that some of teachers examine education program, some of them didn't. In accordance with obtained results, teacher should be master on program in "Human Rights, Civic and Democracy" course as implementation of all course, teacher who are not possessive would live problem in implantation. When results are examined, it is understood that teachers expect students to notice human rights and democracy in content of this course and gain good citizen features. It is obvious that this course which is introduced in 2015-2016 education years is important and would have positive impacts on education process by a right and proper decision. However, it is recognized that participation of all students to lesson becomes harder because of long texts and many unknown words. This result has similarity with study which Bağlı (2013) have done and in this study, students expressed that information isn't enough and narrow concept related to right and freedom is presented in courses. Teachers expressed that allocated time to course is enough, but we have difficulty to fulfill some topics in time because of long texts. According to this result, it is emphasized that topics would be understood easier by shorter, simple and understandable texts. When ideas of Gürel (2016) regarding this course are examined, he puts forward that teachers have material, teacher and course caused troubles and it is seen that elimination of material lack and source inadequacy problems would be convenient and necessary. Additionally, it is presented that knowledge stays in theory because of fewness if course hours and lack of course book. In another similar study, lack of course hours, intensity of content and necessity to evaluate course in process focused is emphasized (Başaran, 2007). Teachers indicate that activities should be given place to concretize intangible concepts within this course, content of course should be simplified and evaluation by process should be given weight rather than evaluation by grade. In a study that support this result, it is emphasized that texts are intangible, simplification is necessary, and process focused evaluation should be done (Balbağ, Bayır \& Ersoy, 2017). It is understood that even mostly question, answer, expression methods are used in teaching of course, implementation like discussion, group work, brain storm, visual presentation are also given place. In a study that supports this result, enhancement of education process by different techniques and method in accordance with course topics would be beneficial (Dolanbay, 2016). It is understood that teachers think this course is important and necessary, but they didn't take any education like training, seminar on implementation of course. It is seen that half of the school managers exhibit positive attitude on "Human Rights, Civic and Democracy" course. It can be said that role behaviors of school managers have positive contribution to this course.

As a result, it is thought that start to implement "Human Rights, Civic and Democracy" course is a right and proper decision. When encountered problems are solved in implementation, individuals would perceive how to be better citizen from primary school by understanding importance of human rights and democracy. By this way, individuals would cover important distance in personal development and advancement in social harmony. As results of study, these recommendations have been given place.

- Texts in "Human Rights, Civic and Democracy" course books should be simplified and its regulation in a way to understand easy is necessary. 
- It would be appropriate that teachers should take educational seminars that are given on to implementation level of course to improve themselves in "Human Rights, Civic and Democracy" course topic and become more competent and aware.

- Dissertations and studies that can make contribution to relevant field literature regarding development of theoretical and implementation dimension of "Human Rights, Civic and Democracy" course, can be increased in quantity and quality.

- Helpful sources, visuals and videos to course can be prepared and published on websites that teachers follow.

- This work is limited to a small group. Researchers can conduct research on the subject with different groups by expanding the subject and scope.

\section{References}

Akbaşlı, S. (2009). Sosyal Bilgiler Öğretiminde Vatandaşlık ve İnsan Hakları Ĕgitimi, Sosyal Bilgiler Öğretiminde Yeni Yaklaşımlar-1, (Ed. Refik Turan, Ali Murat Sünbül, Hakan Akdağ), Ankara: Pegem Yayıncılık.

Andreopoulos, G. (2002). Human Rights Education And Training For Professionals. International Review of Education - Internationale Zeitschrift für Erziehungswissenschaft - Revue Internationale de l'Education, 48, 239-249.

Bağlı, M. Türkan. (2013). Ara-Disiplin Olarak Vatandaşlık ve İnsan Hakları Eğitimi: İlköğretim Öğrencilerinin İnsan Haklarına İlişkin Görüşleri. Eğitim ve Bilim, 38(169), 296-310.

Balbağ, N. L., Gündoğan Bayır, Ö., \& Ersoy, A. F. (2017). İnsan Hakları, Yurttaşlık ve Demokrasi Dersini Öğretmenler ve Öğrenciler Nasıl Alg1lıyor? Sakarya University Journal of Education, 7(1), $223-241$.

Başaran, T. (2007). Ilköğretim Okullarında Vatandaşlık ve Insan Hakları Eğitimi Programının Uygulanışına İlişkin Sosyal Bilgiler Öğretmenlerinin Görüşleri. Yayımlanmamış Yüksek Lisans Tezi. Trakya Üniversitesi, Sosyal Bilimler Enstitüsü, Edirne.

Dolanbay, H. (2016). Sosyal Bilgiler Öğretmen Adaylarının İnsan Hakları ve Demokrasi Dersine İlişkin Görüşleri. Marmara Coğrafya Dergisi, 33, 135-154. https://doi.org/10.14781/mcd.61070

Gürel, D. (2016). Sınıf ve Sosyal Bilgiler Öğretmenlerinin İlkokul 4. Sınıf İnsan Hakları, Yurttaşlık ve Demokrasi Dersine Yönelik Görüşlerinin Karşılıklı Olarak İncelenmesi, Ahi Evran Üniversitesi Kırşehir Eğitim Fakültesi Dergisi (KEFAD), 17(3), 643

Howe, R. Brian \& Covell, K. (2005). Empowering Children, Children's Rights Education as a Pathway to Citizenship. University of Toronto Press.

M.E.B. (2017). İlkokul (4.Sınıf) İnsan Hakları, Yurttaşlık ve Demokrasi Dersi. Retrieved from http://www.eba.gov.tr/ekitap?icerik-id=2973

M.E.B. Talim \& Terbiye Kurulu Başkanlığı. (2015). İlkokul (4.Sınıf) İnsan Hakları, Yurttaşlık ve Demokrasi Dersi (Taslak) Öğretim $\quad$ Programı. Retrieved from http://www.memurlar.net/common/news/documents/514692/14111028_insan_haklari_yurttalkvedemokrasi_tasl ak.pdf

Özbek, R. (2017). Vatandaşlık Ve İnsan Hakları Eğitimi Ders Amaçlarının Gerçekleşme Düzeyi, Inönü Üniversitesi Eğitim Fakültesi Dergisi, 18(1), 359-371. https://doi.org/10.17679/inuefd.302771

Starkey, H. (2002). Democratıc Citızenshıp, Languages, Diversity And Human Rıghts, Language Policy Division Directorate of School, Out-of-School and Higher Education DGIV Council of Europe, Strasbourg.

Yıldırım, A., \& Şimşek, H. (2008). Sosyal Bilimlerde Nitel Araştırma Yöntemleri. (6.Baskı). Ankara: Seçkin Yayıncilik.

\section{Note}

Note 1. This study was produced in the oral presentation presented at IVth International Eurasian Educational Research Congress-EJER 2017. 